University of Nebraska - Lincoln

DigitalCommons@University of Nebraska - Lincoln

The genetic diversity, relationships, and potential for biological control of the lobate lac scale, Paratachardina pseudolobata Kondo \& Gullan (Hemiptera: Coccoidea: Kerriidae)

\author{
S. Schroer \\ University of Florida \\ R. W. Pemberton \\ USDA-Agricultural Research Service \\ L. G. Cook \\ University of Queensland \\ T. Kondo \\ University of California \\ P. J. Gullan \\ University of California
}

Follow this and additional works at: https://digitalcommons.unl.edu/usdaarsfacpub

Part of the Agricultural Science Commons

Schroer, S.; Pemberton, R. W.; Cook, L. G.; Kondo, T.; and Gullan, P. J., "The genetic diversity, relationships, and potential for biological control of the lobate lac scale, Paratachardina pseudolobata Kondo \& Gullan (Hemiptera: Coccoidea: Kerriidae)" (2008). Publications from USDA-ARS / UNL Faculty. 371.

https://digitalcommons.unl.edu/usdaarsfacpub/371

This Article is brought to you for free and open access by the U.S. Department of Agriculture: Agricultural Research Service, Lincoln, Nebraska at DigitalCommons@University of Nebraska - Lincoln. It has been accepted for inclusion in Publications from USDA-ARS / UNL Faculty by an authorized administrator of DigitalCommons@University of Nebraska - Lincoln. 


\title{
The genetic diversity, relationships, and potential for biological control of the lobate lac scale, Paratachardina pseudolobata Kondo \& Gullan (Hemiptera: Coccoidea: Kerriidae)
}

\author{
S. Schroer ${ }^{\mathrm{a}, *}$, R.W. Pemberton ${ }^{\text {b }}$, L.G. Cook $^{\text {c }}$, T. Kondo ${ }^{\text {d, P.J. Gullan }}{ }^{\mathrm{d}}$ \\ ${ }^{a}$ Department of Entomology and Nematology, University of Florida, 3205 College Avenue, Davie, FL 33314, USA \\ ${ }^{\mathrm{b}}$ Invasive Plant Research Laboratory, USDA-Agricultural Research Service, 3225 College Ave, Ft. Lauderdale, FL 33312, USA \\ ${ }^{\mathrm{c}}$ School of Integrative Biology, The University of Queensland, Brisbane 4072, Australia \\ ${ }^{\mathrm{d}}$ Department of Entomology, University of California, One Shields Avenue, Davis, CA 95616-8585, USA
}

Received 7 December 2007; accepted 10 April 2008

Available online 18 April 2008

\begin{abstract}
The lobate lac scale Paratachardina pseudolobata Kondo \& Gullan (Kerriidae) is a polyphagous pest of woody plants in Florida (U.S.A.) the Bahamas, Christmas Island (Australia) and it has been reported from Cuba. Its recent appearance as a pest in these places indicates that this scale is introduced; however, its native range is unknown. Until 2006, this pest species was identified mistakenly as Paratachardina lobata (Chamberlin) [now P. silvestri (Mahdihassan)], which is native to India and Sri Lanka. Quarantine laboratory acceptance trials with Indian $P$. silvestri parasitoids indicated a strong immune response from $P$. pseudolobata. Gregarious development of encyrtid wasps was the only observed parasitism, but parasitization levels were below $3 \%$. Identification of the native range of $P$. pseudolobata would facilitate the search for natural enemies better adapted to the scale. Sequence data from the D2-D3 region of the nuclear large subunit ribosomal RNA gene (LSU rRNA, 28S) and the mitochondrial gene cytochrome oxidase I (COI) distinguished $P$. pseudolobata from the morphologically similar species $P$. silvestri and $P$. mahdihassani Kondo \& Gullan, and showed $P$. pseudolobata to be more closely related to these Indotropical species than to an Australian species of Paratachardina Balachowsky. Paratachardina pseudolobata was genetically uniform throughout its exotic range, consistent with a single geographic origin, although lack of variation in these genes is not unusual for scale insects. Molecular identification of morphologically similar Paratachardina species was possible using the D2-D3 region of $28 \mathrm{~S}$, despite its length variation, suggesting that this gene region might be suitable as a non-COI barcoding gene for scale insects.
\end{abstract}

Published by Elsevier Inc.

Keywords: Native range; Invasive; Cytochrome oxidase I; Nuclear large subunit ribosomal RNA gene (LSU rRNA, 28S); Parasitism; Encyrtidae

\section{Introduction}

The lobate lac scale, a serious plant pest, was first detected in the Bahamas in 1992 and later in South Florida, in Broward County in 1999 and in Miami Dade County in

\footnotetext{
* Corresponding author. Fax: +1954 4769169.

E-mail addresses: Sibylle.Schroer@gmail.com (S. Schroer), Robert. Pemberton@ars.usda.gov (R.W. Pemberton), 1.cook@uq.edu.au (L.G. Cook), scalebug@gmail.com (T. Kondo), pjgullan@ucdavis.edu (P.J. Gullan).
}

2000, where it built up alarming densities in the following two years (Howard and Pemberton, 2003; Pemberton, 2003a). The invasive pest was identified mistakenly as Paratachardina lobata Chamberlin [now a junior synonym of $P$. silvestri (Mahdihassan)] in all literature until the taxonomic revision of the genus Paratachardina Balachowsky by Kondo and Gullan (2007), in which it was described as a new species, Paratachardina pseudolobata Kondo and Gullan. This pest is highly polyphagous: over 300 plant species in 58 different families, including native plants and cultivated fruit trees and ornamentals, are attacked by 
the invasive scale in southern Florida (Howard et al., 2006). Due to the lack of natural enemies, the scale increased and spread quickly in Florida and the Bahamas and has a high potential to spread in the Caribbean and elsewhere (Pemberton, 2003b). The scale was reported from the territory of Christmas Island, Australia (Kondo and Gullan, 2007; Abbott and Green, 2007), where it is a pest of carambola (Averrhoa carambola L.) and other plants (Pemberton, unpublished). Recently it was recorded in Cuba for the first time (Mestre et al., 2006). Efficient natural enemies are needed urgently to control the scale's damage and to limit its spread. Thus identifying the native range of this scale insect is a necessary first step. A biological control research program against the lobate lac scale was initiated in 2003 (Pemberton, 2003b). The first approach was to collect parasitoids from the con-familial and commercially reared Kerria lacca (Kerr), which is host to some parasitoid species known to attack Paratachardina species (Varshney, 1976; Pemberton, 2003b). Three chalcidoid species recorded as parasitizing both $K$. lacca and $P$. lobata (now $P$. silvestri) were collected from $K$. lacca in Thailand and exposed to P. pseudolobata in the USDA, ARS Invasive Plant Research quarantine facility in Florida, but the wasps failed to parasitize the lobate lac scales (Pemberton et al., 2006).

The second approach was to search for the lobate lac scale and its natural enemies in its native range. The search began in India, because the lobate lac scale was previously identified as $P$. lobata, which was known to be native to southern India and Sri Lanka (Varshney, 1977). Robert Pemberton and P. Selvaraj located kerriid scales in India in 2005 at 14 sites. Living kerriid specimens were sent to the USDA, ARS Invasive Plant Research quarantine facility (Schroer et al., 2007). The scales from India were understood to be $P$. lobata as was the target pest in Florida. The Indian material was subsequently identified as $P$. silvestri and $P$. mahdihassani Kondo and Gullan, and the Florida pest as P. pseudolobata (Kondo and Gullan, 2007). Three primary parasitoids of $P$. silvestri and $P$. mahdihassani were isolated, and exposed to P. pseudolobata cultures reared from Florida collections. Despite the observed oviposition, only a few individual wasps were able to develop in lobate lac scales. Most parasitoid eggs were encapsulated by the host, indicating that the parasitoids are not well adapted to lobate lac scale (Schroer and Pemberton, 2007). Parasitoids that have evolved with particular hosts overcome the specific defensive reactions of their hosts, either by avoiding tissue with strong immune reactions or diminishing the chemical reactions with specific venoms or by abilities to disguise the alien tissue (Strand and Pech, 1995).

The apparent mismatch between the parasitoids and the lobate lac scale suggested that the Indian host of the parasitoids and the lobate lac in Florida (both identified as $P$. lobata prior to the taxonomic work of Kondo and Gullan (2007)) might be different species or biotypes. Kondo and Gullan (2007) re-examined the morphology of the invasive lobate lac scale from Florida, the Bahamas and Christmas
Island, as well as other Paratachardina specimens from museum collections and recent Indian collections. They revised the taxonomy of the genus and determined that the lobate lac scale represented a distinct species on the basis of morphological comparisons. The specific name "pseudolobata" was coined in reference to the species with which it had been confused.

For the present study, specimens of $P$. pseudolobata from Florida and the Bahamas were collected to document levels of scale infestation and to record the presence of any parasitoids. Specimens from Florida, the Bahamas, Cuba and Christmas Island were obtained for molecular analysis to estimate the genetic diversity of the populations. We also used DNA sequence data to test the species status of $P$. pseudolobata and to place it in a phylogenetic context by comparison with other species of Paratachardina and with other genera of Kerriidae. Knowledge of the relationship of $P$. pseudolobata to other members of Paratachardina could narrow the search for the native range of the lobate lac scale based on the known distribution of its closest relatives, as done for the pestiferous Chinese wax scale (Qin et al., 1994). In contrast to the morphologically similar $P$. silvestri, the lobate lac scale is exclusively parthenogenetic (Pemberton, 2003a; Howard et al, 2006; Kondo and Gullan, 2007). We could expect that if the populations of $P$. pseudolobata originated from a single geographic region, or represent a single origin of an invasive form, there should be low (possibly zero) genetic variation within pest populations and among different geographical regions of its invasive range (e.g. Downie, 2002; Scheffer and Grissell, 2003; Grapputo et al., 2005). This study also provides the opportunity to evaluate the two genes used here for their usefulness as non-COI barcode regions for molecular identification of scale insects. To date, the typical DNA barcode region ( $5^{\prime}$ region of $\mathrm{COl}$ (Herbert et al., 2003)) has not been reliably or successfully amplified for scale insects using universal or modified primers. Therefore, alternative barcode regions need to be explored. To be useful as a DNA barcode, a region needs to be easily and reliably amplified for the group of interest with universal primers, and to readily distinguish among species.

\section{Materials and methods}

\subsection{Specimen collections}

Specimens were obtained from as many populations and species of Paratachardina as possible (Table 1). Specimens of $P$. pseudolobata were collected from Florida, three islands of the Bahamas, Christmas Island (Australia) and Cuba. Specimens of other Paratachardina species, including $P$. silvestri and $P$. mahdihassani were obtained from several localities in India. Also, because the monophyly of Paratachardina has not been tested and the relationships within the genus are uncertain, sampling included an Australian species of Paratachardina and other lac scales from 
Table 1

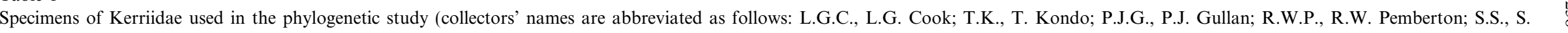
Schroer); DNA vouchers of L.G.C. are in ANIC and those of T.K. are in the BME; T.K. and P.J.G. identified the Paratachardina species, P.J.G. identified the kerriid outgroup species

\begin{tabular}{|c|c|c|c|c|c|c|c|}
\hline Scale species & Voucher code & Host plant & Collectior & & & GenBank & GenBank \\
\hline & & & Location & Date & Collector & $\begin{array}{l}\text { Accession } 285 \\
D 2-D 3\end{array}$ & iccession \\
\hline
\end{tabular}

Paratachardina

TK0415

Callitris glaucophylla

Australia, N.S.W., $1 \mathrm{~km} \mathrm{~N} \mathrm{Gummin} \mathrm{Gummin}$

14.viii.2004 PJG

P. mahdihassani Kondo \& Gullan TK0396

Pongamia pinnata

Andia, Karnataka, Bangalore, Big Banyan Park

P Selvaraj \& RWP

TK0409

Pongamia pinnata

TK041

Pongamia pinnata

India,

India, Karnataka, Bangalore, Jarakabande State vi.2006

P. Selvaraj \& RWP

Forest

P. pseudolobata Kondo \& Gullan TK0117 Clusia sp.

TK0391 Celtis timorensis

TK0392 Celtis timorensis

TK0393 Celtis timorensis

TK0388

TK0398

Celtis timorensis

TK0399

Melaleuca vinifera

TK0400

Psychotria nervosa

Myrica cerifera

TK0402

Unidentified host

TK0403

Tetrazygia bicolor

TK0404

TK0405

TK0406 Chrysobalanus icaco

Eugenia confusa

Unidentified host

Unidentified host

USA, Florid

Lauderdale

Australia, Christmas Island, Dolly Beach Track

20.xi. 2002

P. Selvaraj \& RWP

Ficus benjamina

P. silvestri Mahdihassan

TK0559

TK0344

TK0397

Pongamia pinnata

Australia, Christmas Island, Daniel Roux Road

15.vi.2006

TK

Australia, Christmas Island, Winifred Beach

15.vi.2006

K. Retallick

Track

USA, Florida, CR997/US 41

. Retallic

19.vi.2006 R. Reeves

USA, Florida, Broward, Fern Forest, $\quad$ 14.vi.2006 SS \& RWP

8.vi.2006 SS \& RWP

USA, Florida, Big Cypress Seminole Indian 8 vi.2006 SS \& RWP

Reservation

Bahamas, New Providence, Nassau, viii.2006

Bahamas, Grand Bahamas, Rand Nature Center, viii.2006

Bahamas, Grand Bahamas,

Bahamas, Andros

Bahamas, Andros,

Bahamas, Andros

Cuba, Universidad Central de Las Villas,

Facultad de Ciencias Agropecuarias

India, Karnataka, Bangalore, Malleshwaram 1-5.v.2006 P. Selvaraj \& RWP

Circle

TK0345 Pongamia pinnata

TK0410 Pongamia pinnata

India, Tamil Nadu, Coimbator, Onapalayam

2006

P. Selvaraj \& RWP

India, Tamil Nadu, Coimbator, Onapalayam

vi.2006

P. Selvaraj \& RWP

Outgroup kerriids

Austrotachardia acaciae

LGC00299

Acacia, probably A. aneura

Australia, Northern Territory, outside Alice

4.x.2004

LGC

A. near acaciae

LGC00380

Acacia papyrocarpa

Austrotachardia near melaleucae

LGC00395

(Maskell)

A. near melaleucae

LGC00206

Calothamnus quadrifidus

Pustralia, South Australia, $52 \mathrm{~km}$ E of Kimba,

4.ix. 2005

LGC

Polygonum Tank

Melaleuca strobophylla site

A. near melaleucae

LGC00249

Melaleuca $\mathrm{sp}$.

Australia, Western Australia, Lake King to

10.ix.2005 LGC

Southern Cross Rd

Australia, Western Australia, $30 \mathrm{~km} \mathrm{NE}$ of Lake 1.ix.2004 LGC \& M.D. Crisp

A. near melaleucae

LGC00432

Melaleuca sparsiflora

Unidentified

Australia, Western Australia, $51 \mathrm{~km} \mathrm{~W}$ of Kamarl 16.ix.2005 LGC

Australia, Western Australia, $76 \mathrm{~km} \mathrm{~S}$ of

18.ix.2005 LGC

Newdegate along Lake Magenta Road 
Australia and Africa, which served as outgroups for phylogenetic analysis (Table 1).

For the lobate lac scale and the Indian Paratachardina species, infested twig segments were clipped from the plants and samples of about 10-30 specimens were stored in each of $70 \%$ and $95 \%$ ethanol for transportation to the Department of Entomology, UC Davis. Specimens of P. silvestri and $P$. mahdihassani were taken from shipments sent bimonthly from 14 sites in southern India from August 2005 until July 2006 (Schroer et al., 2007). Lobate lac scales from Christmas Island were provided by Dennis O'Dowd (Monash University, Australia) and Mick Jeffery (Parks Australia North, Christmas Island), from Cuba by Horacio Grillo Ravelo (Universidad Central de Las Villas, Cuba). In Florida, $P$. pseudolobata was collected at 12 sites. The sites were selected from a list of lobate lac scale collection localities provided by Greg Hodges (Florida Department of Agriculture and Consumer Services, Gainesville, FL). In the Bahamas, P. pseudolobata specimens were collected from three islands: Grand Bahamas, New Providence and Andros.

The density of $P$. pseudolobata infestations in Florida and the Bahamas was determined per plant with the highest infestation at each site, by estimating the number of lobate lac scales per $30 \mathrm{~cm}$ of three randomly chosen twig segments with $\leqslant 20 \mathrm{~mm}$ cross-section. Infestations of $\leqslant 10$ female scales were rated as low, $\geqslant 11-100$ as medium, and $>100$ as high (Pemberton, 2003a). From each collection site, scales on $30 \mathrm{~cm}$ twig segments with highest infestation were examined for the presence of parasitoid emergence holes. The percentage parasitization was determined by counting the number of emergence holes relative to the number of scales. Data were compared using one tailed Mann-Whitney $U$ test for two independent samples. Due to the low percentage of parasitization we did not arcsine transform these data; significant levels were at $5 \%$. If the tests had emergence holes, the specimens were removed and preserved in ethanol, and remains of parasitoids inside the scales were studied under the dissecting microscope.

\subsection{Identification and morphological observations}

Identifications and morphological observations of all Kerriidae available for this study were made from adult females mounted on microscope slides and examined under a compound microscope. Specimens were slide-mounted in Canada balsam using the method described in Williams and Granara de Willink (1992), except that xylene was used instead of clove oil. Specimens intended for molecular work were preserved in $95-100 \%$ ethanol and stored below $4{ }^{\circ} \mathrm{C}$. After DNA extraction, these specimens were slidemounted as vouchers. All vouchers of Paratachardina species are deposited in the Bohart Museum of Entomology (BME), University of California, Davis, USA, although other specimens from these same collections are deposited in a range of institutions (Kondo and Gullan, 2007). Vou- 
cher specimens for outgroup taxa will be deposited either in $\mathrm{BME}$ or the Australian National Insect Collection (ANIC), CSIRO Entomology, Canberra. The collection data and depositories for voucher specimens are listed in Table 1.

\subsection{Molecular comparisons}

DNA was extracted from whole, ethanol-preserved adult female specimens using a DNeasy Blood and Tissue Kit (Qiagen) following the manufacturer's instructions. The cuticle of each adult female was recovered after the first incubation step and stored in $70 \%$ ethanol until being slide-mounted. Two partial gene regions were amplified; the $3^{\prime}$ region of the mitochondrial protein-encoding gene cytochrome oxidase I (COI) was amplified with an annealing temperature of $50{ }^{\circ} \mathrm{C}$ using CI-J-2183 (Jerry) (Simon et al., 1994) and C1-N-2568 (Ben) (Brady et al., 2000), and the D2-D3 region of the nuclear large-subunit ribosomal RNA gene (28S) was amplified with an annealing temperature of $55^{\circ} \mathrm{C}$ using primers S3660 (28SF, Dowton and Austin, 1998) and A335 (28Sb, Whiting et al., 1997). The COI barcode region (Herbert et al., 2003) was not used because it has failed to amplify in most scale insects tried to date, including lac scales. Purified PCR products were sequenced in both the forward and reverse directions at the UC Davis genomics facility (CGF, UC Davis) or by Macrogen Ltd. (Korea).

Contigs were assembled and manually edited using Sequencher v4.5 (Gibbs and Cockerill, 1995; GeneCodes) and aligned by eye using Se-Al (Rambaut, 1996). Phylogenetic analyses and genetic distance measures were undertaken using PAUP* (Swofford, 2003). Genetic distance measures were calculated using the Kimura-2 parameter option. Length variation in the D2-D3 region of $28 \mathrm{~S}$ among lac scale taxa resulted in regions of ambiguous alignment. These regions were excluded from analyses that included sampling across the whole of Kerriidae. There was less length variation within Paratachardina, resulting in a less ambiguous alignment, so all sites were included in a reduced-taxon, Paratachardina-only analysis. Two different weighting schemes were applied in maximum parsimony analysis (MP) of the COI data: equally-weighted (ewt MP, all sites weighted equally) and differentially-weighted (dwt MP, in which first and second codon positions were weighted three times that of third codon positions).

For a gene region to be of use as a DNA barcode, an unknown sample needs to be reliably and confidently matched to a known sample, typically using a phylogenetic approach such as neighbor-joining. Length variation among samples has the potential to mislead analyses if the phylogenetic result is sensitive to alignment. To test the utility of $28 \mathrm{~S}$, despite its length variation within scale insects, an automated alignment program (MUSCLE, Edgar, 2004) was used to determine whether the species clusters could be recovered using a default ambiguous alignment of the whole of the D2-D3 region. The MUS-
CLE alignment was analyzed using the neighbor-joining (NJ) option (Kimura-2 parameter) in PAUP*.

\section{Results}

\subsection{Colonization and parasitism}

In southern Florida most sampled host plants were heavily infested with $P$. pseudolobata. Infested plants were found over the entire southern peninsula from the east to the west coast between latitudes $25^{\circ} 00^{\prime} \mathrm{N}$ to $27^{\circ} 46^{\prime} \mathrm{N}$, including seven counties. In Miami-Dade and Broward Counties susceptible plants were infested with $>500$ scales per $30 \mathrm{~cm}$. Wax myrtle (Myrica cerifera) and redberry stopper (Eugenia confusa) were among the most susceptible plants to $P$. pseudolobata in Florida and usually were the first infested plant species at newly invaded sites. At the most northern site in Florida and the most eastern site on Andros Island, these two plant species had infestation levels of $>300$ scales per $30 \mathrm{~cm}$. In the three islands of the Bahamas, the infestation was lower than in Florida, but occasional very high infestations were recorded (e.g., $>400$ adult scales per $30 \mathrm{~cm}$ were counted on a redberry stopper on Grand Bahamas Island). Plants infested to a medium level were found throughout the observed islands. Table 2 presents the infestation levels and the number of scales found with parasitoid emergence holes at all collection sites in the Bahamas and Florida.

The parasitization level of $P$. pseudolobata was very low. In the Bahamas only $2.29 \%$ ( \pm 3.31$)$ scales ( $n=2557$ scales) were parasitized. and even less $0.22 \%( \pm 0.37)$ were parasitized in southern Florida ( $n=10860$ scales), (Mann-Whitney Test, $P=0.23$ ). Fully developed adults of Metaphycus spp. and Ooencyrtus sp. (Hymenoptera: Encyrtidae) were found inside scales both in Florida and the Bahamas. A Metaphycus male and female were found inside a single scale on the Bahamas, and two males and one female were collected in Florida. Only males were found of Ooencyrtus, two on the Bahamas and one in Florida. All collected parasitoids developed gregariously with two to four siblings as indicated by the number of emergence holes and parasitoid remains found in the scales.

\subsection{Morphological characteristics}

Morphologically, $P$. pseudolobata is similar to two Indian species, $P$. mahdihassani and $P$. silvestri (Kondo and Gullan, 2007). In each of these three species, the test of the adult female is resinous and four-lobed. In the other species of Paratachardina, the test of the adult female is more globular and has up to 16 ridges radiating from the top center of the test towards the venter, giving a ribbed appearance. The morphology of adult females of all Paratachardina species is quite similar in structure and reliable identification requires well-prepared microscope slide-mounts. The most important features for distinguish- 
Table 2

Sites and host plants of Paratachardina pseudolobata collections in the Bahamas and Florida from east to west, indicating the level of scale infestation (Inf) per plant, counted as low (1), medium (m) or high (h), with 0 to 10,10 to 100 and $>100$ mature females per $30 \mathrm{~cm}$, respectively, and the total number of scales with parasitoid emergence holes (Eh) per stem segment

\begin{tabular}{|c|c|c|c|c|c|c|}
\hline \multirow[t]{2}{*}{ Location and habitat } & \multicolumn{2}{|c|}{ GPS coordinates } & \multirow[t]{2}{*}{ Plant species } & \multirow[t]{2}{*}{ Plant family } & \multirow[t]{2}{*}{ Inf } & \multirow[t]{2}{*}{$\mathrm{Eh}$} \\
\hline & West & North & & & & \\
\hline \multicolumn{7}{|l|}{ Bahamas, New Providence } \\
\hline \multirow[t]{3}{*}{ Bahamas Trust retreat } & $077^{\circ} 18.63$ & $25^{\circ} 03.83$ & Guapira discolor & Nyctaginaceae & 1 & 3 \\
\hline & & & Croton eluteria & Euphorbiaceae & $\mathrm{h}$ & 6 \\
\hline & & & Nectandra coriacea & Lauraceae & 1 & 3 \\
\hline \multirow[t]{2}{*}{ Roadside } & $077^{\circ} 19.28$ & $25^{\circ} 04.51$ & Chrysobalanus icaco & Chrysobalanaceae & $\mathrm{h}$ & 0 \\
\hline & $077^{\circ} 26.76$ & $25^{\circ} 03.19$ & Exothea paniculata & Sapindaceae & $\mathrm{m}$ & 1 \\
\hline \multicolumn{7}{|l|}{ Bahamas, Andros } \\
\hline Roadside & $077^{\circ} 45.59$ & $24^{\circ} 35.02$ & unknown species & Rubiaceae & $\mathrm{h}$ & 0 \\
\hline Pineland & $077^{\circ} 45.68$ & $24^{\circ} 41.71$ & Caesalpinia bahamensis & Fabaceae & 1 & 0 \\
\hline \multirow[t]{8}{*}{ Roadside } & $077^{\circ} 47.40$ & $24^{\circ} 41.95$ & Chrysobalanus icaco & Chrysobalanaceae & $\mathrm{m}$ & 0 \\
\hline & & & Psidium sp. & Myrtaceae & 1 & 1 \\
\hline & & & Hypelate trifoliata & Sapindaceae & $\mathrm{m}$ & 3 \\
\hline & & & Chrysobalanus icaco & Chrysobalanaceae & 1 & 0 \\
\hline & $077^{\circ} 47.83$ & $24^{\circ} 44.03$ & unknown species & Sapindaceae & 1 & 0 \\
\hline & $077^{\circ} 48.65$ & $24^{\circ} 48.57$ & Exothea paniculata & Sapindaceae & $\mathrm{m}$ & 0 \\
\hline & $077^{\circ} 53.03$ & $24^{\circ} 49.57$ & Chrysobalanus icaco & Chrysobalanaceae & $\mathrm{h}$ & 0 \\
\hline & $077^{\circ} 59.79$ & $25^{\circ} 10.26$ & Conocarpus erectus var. sericeus & Combretaceae & 1 & 1 \\
\hline Understory in forest & $078^{\circ} 02.42$ & $26^{\circ} 06.67$ & unknown shrub & & 1 & 0 \\
\hline \multicolumn{7}{|l|}{ Bahamas, Grand Bahamas } \\
\hline \multirow{2}{*}{ Mangrove hammock } & $078^{\circ} 24.13$ & $26^{\circ} 36.12$ & unknown tree & & 1 & 1 \\
\hline & & & Coccoloba diversifolia & Polygonaceae & $\mathrm{m}$ & 0 \\
\hline Pineland & $078^{\circ} 24.16$ & $26^{\circ} 36.36$ & Myrica cerifera & Myricaceae & 1 & 0 \\
\hline \multirow[t]{13}{*}{ Rand Nature Centre, hardwood hammock } & $078^{\circ} 40.40$ & $26^{\circ} 32.36$ & Exothea paniculata & Sapindaceae & $\mathrm{h}$ & 0 \\
\hline & & & Lysiloma latisiliquum & Fabaceae & 1 & 0 \\
\hline & & & Metopium toxiferum & Anacardiacaea & 1 & 0 \\
\hline & & & Guettarda elliptica & Rubiaceae & 1 & 0 \\
\hline & & & Tetrazygia bicolor & Melastomataceae & $\mathrm{h}$ & 2 \\
\hline & & & Manilkara zapota & Sapotaceae & $\mathrm{m}$ & 1 \\
\hline & & & unknown shrub & & $\mathrm{m}$ & 3 \\
\hline & $078^{\circ} 40.42$ & $26^{\circ} 32.30$ & unknown shrub & & $\mathrm{h}$ & 3 \\
\hline & & & Myrica cerifera & Myricaceae & $\mathrm{m}$ & 0 \\
\hline & & & Lysiloma latisiliquum & Fabaceae & 1 & 0 \\
\hline & $078^{\circ} 40.50$ & $26^{\circ} 32.24$ & Myrsine floridana & Myrsinaceae & 1 & 0 \\
\hline & & & Schinus terebinthifolius & Anacardiaceae & $\mathrm{m}$ & 0 \\
\hline & & & Metopium toxiferum & Anacardiaceae & $\mathrm{m}$ & 1 \\
\hline Roadside & $078^{\circ} 49.91$ & $26^{\circ} 33.56$ & Chrysobalanus icaco & Chrysobalanaceae & $\mathrm{m}$ & 1 \\
\hline & $078^{\circ} 50.88$ & $26^{\circ} 34.34$ & Eugenia confusa & Myrtaceae & $\mathrm{h}$ & 1 \\
\hline \multicolumn{7}{|l|}{ Florida (County) } \\
\hline Secret Woods, landscaped (Broward) & $080^{\circ} 10.66$ & $26^{\circ} 05.32$ & Psychotria nervosa & Rubiaceae & $\mathrm{h}$ & 0 \\
\hline Fern Forest, hardwood hammock (Broward) & $080^{\circ} 11.09$ & $26^{\circ} 13.78$ & Psychotria nervosa & Rubiaceae & $\mathrm{h}$ & 0 \\
\hline Simpson Park, landscaped (Miami Dade) & $080^{\circ} 11.82$ & $25^{\circ} 45.72$ & Psychotria nervosa & Rubiaceae & $\mathrm{h}$ & 3 \\
\hline University of Florida, nursery plant (Broward) & $080^{\circ} 14.40$ & $26^{\circ} 04.97$ & Randia aculeata & Rubiaceae & $\mathrm{m}$ & 0 \\
\hline Loxahatchee Wildlife Refuge (Palm Beach) & $080^{\circ} 21.70$ & $26^{\circ} 51.99$ & Schinus terebinthifolius & Anacardiaceae & $\mathrm{m}$ & 0 \\
\hline Jungle Trail, landscaped (Indian River) & $080^{\circ} 24.99$ & $27^{\circ} 46.10$ & Myrica cerifera & Myricaceae & $\mathrm{h}$ & 0 \\
\hline Melaleuca infested forest (Miami Dade) & $080^{\circ} 29.20$ & $25^{\circ} 45.93$ & Melaleuca quinquenervia & Myrtaceae & $\mathrm{h}$ & 1 \\
\hline Everglades NP (Miami Dade) & $080^{\circ} 46.03$ & $25^{\circ} 45.41$ & Chrysobalanus icaco & Chrysobalanaceae & $\mathrm{h}$ & 0 \\
\hline I-75, recreation area (Broward) & $080^{\circ} 43.05$ & $26^{\circ} 08.92$ & Myrica cerifera & Myricaceae & $\mathrm{h}$ & 0 \\
\hline Big Cypress national preserve (Monroe) & $080^{\circ} 55.50$ & $25^{\circ} 50.80$ & Myrica cerifera & Myricaceae & $\mathrm{m}$ & 3 \\
\hline Seminole Big Cypress Museum (Hendry) & $081^{\circ} 00.90$ & $26^{\circ} 21.73$ & Myrica cerifera & Myricaceae & $\mathrm{h}$ & 0 \\
\hline Naples, shrub on side of road (Collier) & $081^{\circ} 45.99$ & $26^{\circ} 08.77$ & Chrysobalanus icaco & Chrysobalanaceae & $\mathrm{m}$ & 0 \\
\hline
\end{tabular}

ing the adult females of $P$. pseudolobata from those of $P$. mahdihassani and P. silvestri are (i) the distance between the two microduct clusters of the first pair of ventral duct clusters (vdc-1), and (ii) the total number of pairs of ventral duct clusters; see Kondo and Gullan (2007) for discussion of these features.

\subsection{Molecular identification and relationships}

Paratachardina was recovered as monophyletic in analyses of both gene regions but bootstrap support was weak (Figs. 1 and 2). Paratachardina sp. near decorella (Australia) was sister to the other three species ( $P$. pseudolobata, 
Austrotachardiella colombiana TK0122 Colombia

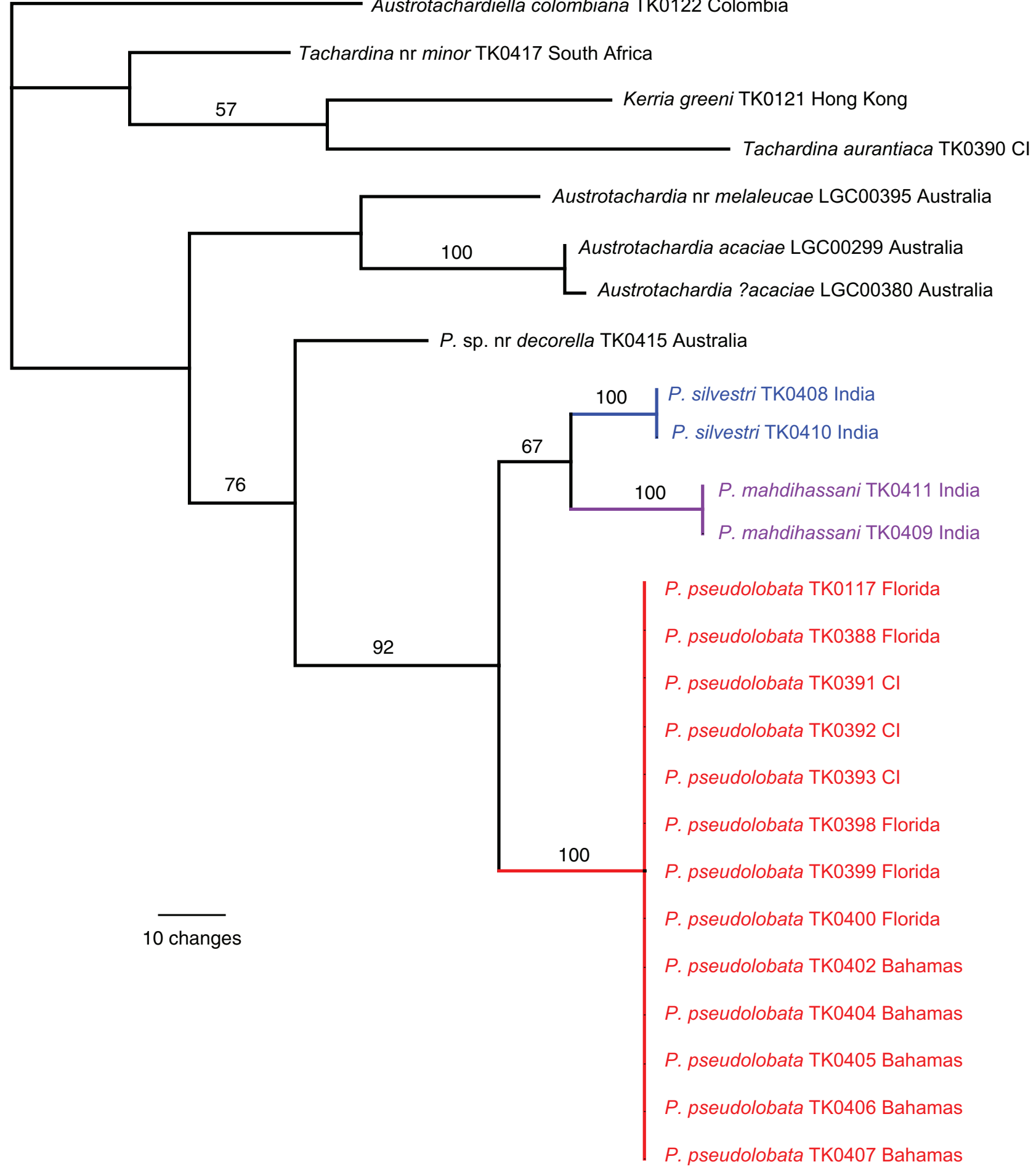

Fig. 1. Phylogenetic relationships of the lac scales (Kerriidae) based on maximum parsimony analysis of COI with codon positions weighted differentially (first and second positions weighted 3, third positions weighted 1). Bootstrap support from 1000 pseudoreplicates is shown above internodes. The specimen code and collection locality are shown after each species name. CI, Christmas Island (Australia).

P. silvestri and P. mahdihassani). All species for which multiple specimens were sampled were recovered as monophyletic. The relationships among P. pseudolobata, P. silvestri and $P$. mahdihassani differed among analyses. In dwt MP analysis of $C O I$ (Fig. 1), and in the Paratachardina-only analysis of $28 \mathrm{~S}$ (Fig. 3), P. silvestri and P. mahdihassani were sister taxa. In the conserved region-only analysis of $28 \mathrm{~S}, P$. silvestri was sister to $P$. pseudolobata, whereas in the ewt MP analysis of COI P. mahdihassani was sister to P. pseudolobata. The NJ analysis of the MUSCLE alignment of $28 \mathrm{~S}$ recovered all species, with each multiply-sampled species of Paratachardina receiving bootstrap values of 100 . 


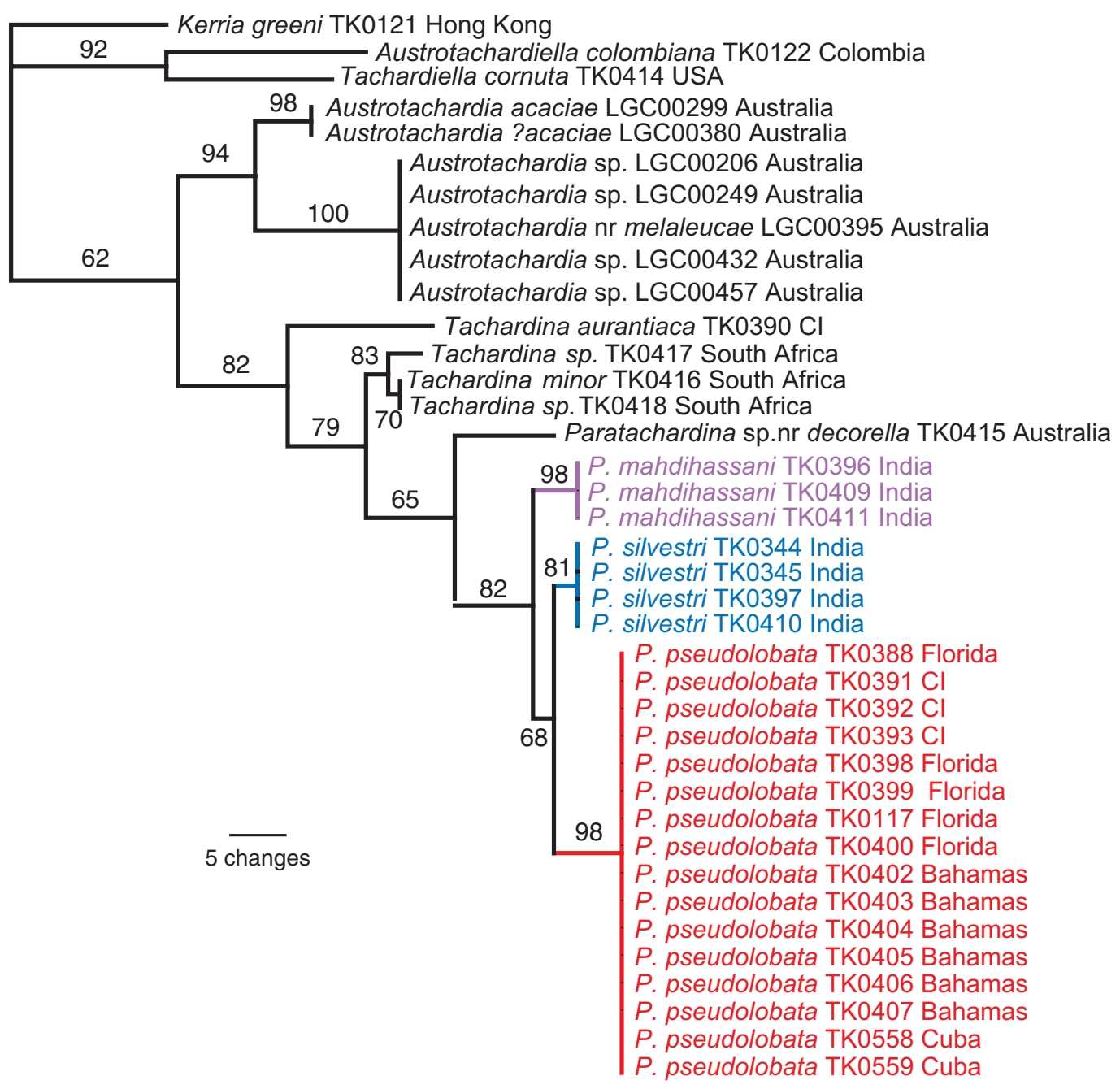

Fig. 2. Phylogenetic relationships of the lac scales (Kerriidae) based on maximum parsimony analysis of the conserved regions of the D2-D3 domains of 28S. Bootstrap support from 1000 pseudoreplicates is shown above internodes. The specimen code and collection locality are shown after each species name. CI, Christmas Island (Australia).

More variation was found within and among taxa in $28 \mathrm{~S}$ than in COI (Figs. 1 and 2). The length of the amplified D2-D3 region of $28 \mathrm{~S}$ varied more than $30 \%$ among the kerriid specimens $(748-1114 \mathrm{bp})$. There was $11 \%$ divergence in $28 \mathrm{~S}$ between $P$. pseudolobata and $P$. mahdihassani, and $12 \%$ between $P$. pseudolobata and P. silvestri. Paratachardina sp. near decorella (TK0415) was the only individual displaying variation in $28 \mathrm{~S}$, with 5 polymorphic sites. At each polymorphic site, both peaks of the electropherogram were of equal intensity. There were both length variation and substitutions among individuals of $P$. silvestri from different localities, with 9 substitutions separating TK0410 from the other two populations. No variation was found within or among populations of either P. pseudolobata or P. mahdihassani.

There was no length variation in the $C O I$ region amplified and no intra-specific polymorphism (Fig. 1), but there was up to $15 \%$ difference within Paratachardina and $7-9 \%$ divergence between $P$. pseudolobata and its nearest relatives. There was $10 \%$ divergence in COI between $P$. pseudolobata and P. mahdihassani, and $8.5 \%$ between
P. pseudolobata and P. silvestri. Of the lac scale insect species compared here, only $P$. silvestri exhibited intra-specific variation in $28 \mathrm{~S}$. None were found to have intra-specific variation in $\mathrm{COI}$.

\section{Discussion}

The level and pattern of DNA sequence divergence between $P$. pseudolobata and other kerriid specimens distinguishes $P$. pseudolobata from the morphologically most similar species $P$. silvestri and $P$. mahdihassani. Both COI and $28 \mathrm{~S}$ clearly distinguished each of the described species of Kerriidae and resulted in clustering of individuals by species in the phylogenetic analyses (Figs. 1 and 2). COI was less variable than $28 \mathrm{~S}$ but easier to align and with less uncertainty. $28 \mathrm{~S}$ was more variable than $C O I$ in proportion of substitutions, presence of indels and fragment length. Scale insect $28 \mathrm{~S}$ appears to be more diverse and length-variable than that of most other insects examined to date (e.g. Dowton and Austin, 1998; Gillespie et al., 2004). This also is the case for the more conserved $18 \mathrm{~S}$ region, in which 


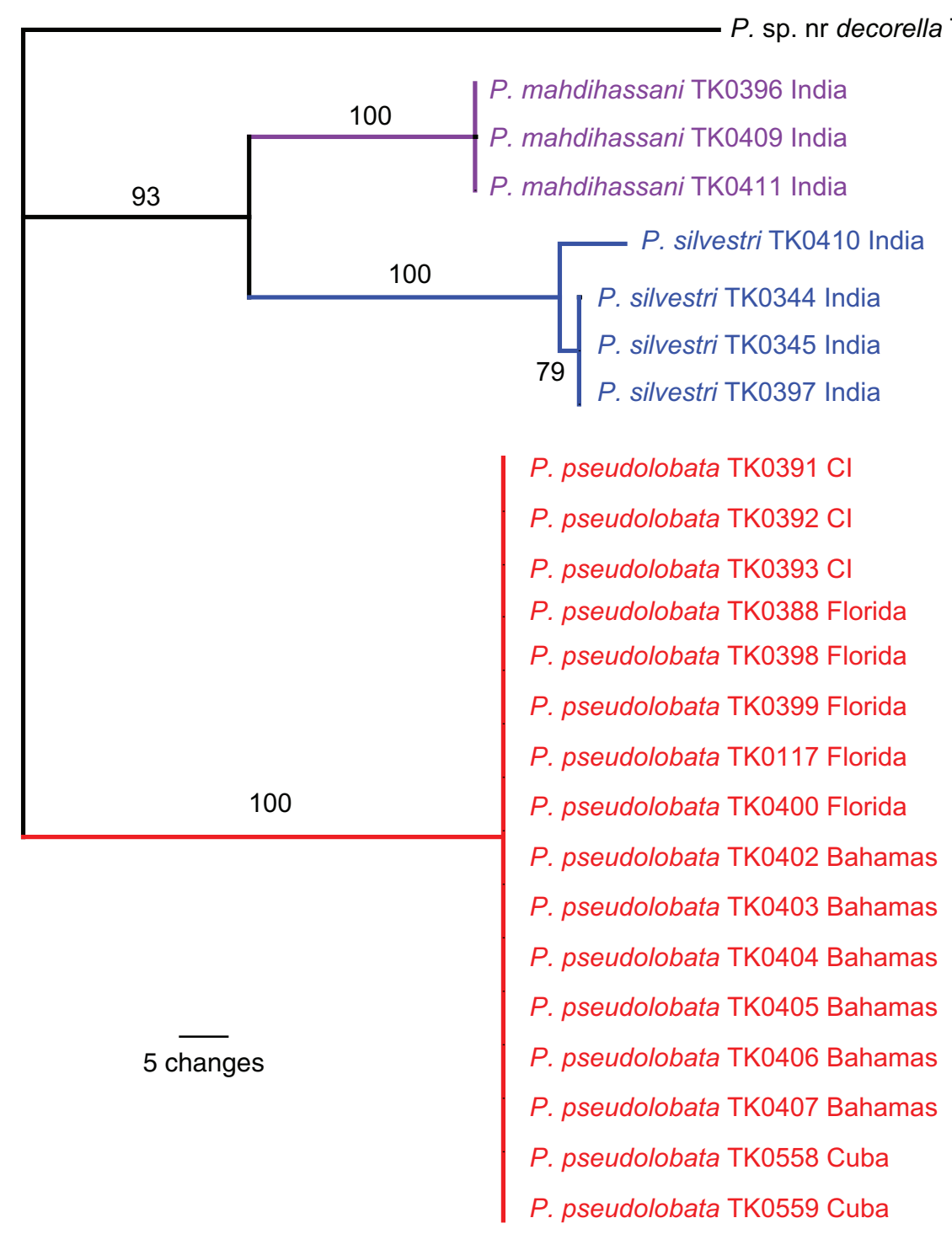

Fig. 3. Phylogenetic relationships within Paratachardina based on maximum parsimony analysis of the D2-D3 regions of 28S. Bootstrap support from 1000 pseudoreplicates is shown above internodes. The specimen code and collection locality are shown after each species name. CI, Christmas Island (Australia).

scale insects also exhibit considerable length variation among taxa (Cook et al., 2002; Cook and Gullan, 2004).

Incomplete concerted evolution, or another process with a similar outcome, is apparent in the $28 \mathrm{~S}$ sequence from $P$. $\mathrm{nr}$ decorella (TK0415), with five clear polymorphic sites in the one individual. The equal intensity of each polymorphism in the electropherogram suggests that each is present in equal copy number. This could indicate that there are two independent loci, each concertedly evolving within a locus but not across loci. Multiple copies of 28S have been reported for insects previously (e.g. Dowton and Austin, 1998; Gillespie et al., 2004) and have sometimes been attributed to multiple loci. An alternative explanation might be recent hybridization, with the TK0415 individual representing an F1-equivalent hybrid.

The combination of extreme length polymorphism among taxa and substitutional polymorphism within individuals suggests that the use of $28 \mathrm{~S}$ as an alternative
DNA barcode region in scale insects might not be straightforward. The variation leads to greater branch length between taxa but difficulty in aligning sequences across diverse taxa, even within Kerriidae. This might not be a major problem if specimen identification is the primary objective. Despite the length variation present within the kerriids included here, specimens were clustered by species with high confidence (bootstraps $=100$ ) using an automated alignment program (MUSCLE) and neighbor-joining algorithm. This suggests that 28S, despite length variation, might be a suitable non-COI barcode for scale insects.

The lack of variation among all specimens of $P$. pseudolobata sampled to date is consistent with a single geographic, or genotypic, origin of the scale. Given the apparent parthenogenetic nature of the populations of $P$. pseudolobata, it is possible that each could have been founded by as few as one female. However, the DNA 
sequence data do not preclude multiple introductions or origins. Although there was no variation among individuals of $P$. pseudolobata from across its sampled introduced range, this is not unusual compared with other scale insects. A lack of variation among populations in the same gene regions has been found also for some other recognized species of scale insects (L.G. Cook, unpublished data). This is despite some species apparently being obligatorily sexual and having been collected from disparate localities in their native range.

No genotype was sampled from India that matched or was conspecific with $P$. pseudolobata, indicating that $P$. pseudolobata may be native to an unsampled region within India, or to another country not yet sampled. In two of the analyses (Figs. 1 and 2) it is sister to species native to India. Thus, these molecular phylogenies are uninformative as to where its native range might be, leaving the whole of Southeast Asia and Australia (the apparent natural range of the genus) as possibilities. Takumasa Kondo examined insect collections of Kasetsart University, Bangkok, and the Department of Agriculture, Bangkhen, Thailand, in 2007. Few Kerriidae were in the dry collections, none slide-mounted, and the material mostly appeared to be Kerria species. No specimens of Paratachardina were found in any collections or in field searches.

In the conserved region-only analysis of $28 \mathrm{~S}$ (Fig. 2), $P$. pseudolobata is nested within the Indian clade, suggesting this area as the possible native range. Sampling has not yet been extensive across India and Sri Lanka, and it is possible that there might be more species of Paratachardina. For instance, $P$. silvestri had considerable variation in $28 \mathrm{~S}$ and the levels, up to 9 substitutions, suggest that further cryptic species may exist in this taxon. The introduction of the lobate lac scale into Florida and the Bahamas is very likely due to the importation of plants infested with this inconspicuous species. The time of the introduction of P. pseudolobata in Christmas Island is unknown. It might have been introduced with plants from Asia, where a high proportion of the human population of Christmas Island originate (Heng and Forbes, 2006). Furthermore, distribution within the New World tropical regions, particularly in the proximate West Indies, might be promoted by further movement of infested horticultural plants, as well as by wind and vectors such as wild animals and humans (Gullan and Kosztarab, 1997).

Despite the close similarity to $P$. silvestri and $P$. mahdihassani, the invasive $P$. pseudolobata is equipped with a different immune response. Parasitoids reared from Indian Paratachardina spp. developed successfully in P. pseudolobata only when multiple parasitoid eggs per scale were laid (Schroer and Pemberton, 2007). In Florida and the Bahamas, the same gregarious parasitoid development was observed for both the Metaphycus and Ooencyrtus spp. These parasitoid species are currently undescribed and their biology is not known; they might be local species that have shifted hosts. Similarly, Ammonoencyrtus carolinensis (Meyer) (Hymenoptera: Encyrtidae), a parasitoid species that was isolated from P. pseudolobata in Florida (Schauff, 2005), is known to attack the coccid Mesolecanium nigrofasciatum (Pergande) and may have shifted recently to the lobate lac insect. The parasitization levels of $P$. pseudolobata in the Bahamas and in Florida are very low. The slightly higher parasitization level in the Bahamas might be due to greater parasitic wasp occurrence, promoted by favorable habitats and more wild areas, untreated with pesticides. However, the parasitization levels are insufficient to influence the abundance of $P$. pseudolobata populations in either region. Further research to investigate the origin and biology of the parasitoids and the habitats where they are most successful parasitizing the lobate lac scale are necessary for the success of future biological control strategies. This effort, although challenging because the native range of $P$. pseudolobata is unknown, will be facilitated by the correct identification of the pest, provided by both the morphological data (Kondo and Gullan, 2007) and the molecular research reported here.

\section{Acknowledgments}

We thank M. Jeffery (Parks Australia North, Christmas Island) and D.J. O'Dowd (Monash University, Australia) who helped us to obtain kerriid specimens from Christmas Island, and H.G. Ravelo (Universidad Central de Las Villas, Cuba) for collecting and shipping scales to BME. We thank P. Selvaraj and B.V. David, Sun Agro Biotech Research Centre, Chennai, India for collecting and shipping scales to the USDA laboratory. A research and collection permit for the Bahamas was provided by S. Pinder Director of the Department of Agriculture Nassau, N.P. Bahamas. Thanks to G. Hodges for providing the list of lac scale occurrence in Florida and M.W. Gates (USDA, ARS, Washington DC) for identifying the chalcidoid wasps. The Western Australian and Northern Territory governments are acknowledged for providing collection permits to L.G. Cook. M.D. Crisp assisted with identification of the host plants of the Australian Kerriidae. The ZOOL3009 (2006) lac-project group from UQ (Penny Mills, Adele Stirling, Chris Reeves and Godfrey Chim) helped generate and edit sequences for some of the lac scales included in this study. This work was supported in part by an Australian Research Council Discovery Grant (to L.G. Cook), the South Florida Water Management District, the USDA-APHIS, and by the U.S. National Science Foundation (Partnership for Enhancing Expertise in Taxonomy program, under Grant No. 0118718 to P.J. Gullan) and by Hatch funding from the California Agricultural Experiment Station to P.J. Gullan.

\section{References}

Abbott, K.L., Green, P.T., 2007. Collapse of an ant-scale mutualism in a rainforest on Christmas Island. Oikos 116, 12381246.

Brady, S.G., Gadau, J., Ward, P.S., 2000. Systematics of the ant genus Camponotus (Hymenoptera: Formicidae): a preliminary analysis using 
data from the mitochondrial gene cytochrome oxidase I. In: Austin, A.D., Dowton, M. (Eds.), Hymenoptera: Evolution, Biodiversity and Biological Control. CSIRO Publishing, Collingwood, pp. 131-139.

Cook, L.G., Gullan, P.J., 2004. The gall-inducing habit has evolved multiple times among the eriococcid scale insects (Sternorrhyncha: Coccoidea: Eriococcidae). Biological Journal of the Linnean Society 83, 441-452.

Cook, L.G., Gullan, P.J., Trueman, H.E., 2002. A preliminary phylogeny of the scale insects (Hemiptera: Sternorrhyncha: Coccoidea) based on nuclear small-subunit ribosomal DNA. Molecular Phylogenetics and Evolution 25, 43-52.

Downie, D.A., 2002. Locating the sources of an invasive pest, grape phylloxera, using mitochondrial DNA gene genealogy. Molecular Ecology 11, 2013-2026.

Dowton, M., Austin, A.D., 1998. Phylogenetic relationships among the microgastroid wasps (Hymenoptera: Braconidae): combined analysis of $16 \mathrm{~S}$ and $28 \mathrm{~S}$ rDNA genes and morphological data. Molecular Phylogenetics and Evolution 10, 354-366.

Edgar, R.C., 2004. MUSCLE: a multiple sequence alignment method with reduced time and space complexity. BMC Bioinformatics 5, 113.

Gibbs, R.A., Cockerill, M., 1995. Sequencher, third ed. Ann Arbor: Gene Codes Corporation.

Gillespie, J., Cannone, J., Gutell, R., Cognato, A., 2004. A secondary structural model of the 28S rRNA expansion segments D2 and D3 from rootworms and related leaf beetles (Coleoptera: Chrysomelidae: Galerucinae). Insect Molecular Biology 13, 495-518.

Grapputo, A., Boman, S., Lindström, L., Lyytinen, A., Mappes, J., 2005. The voyage of an invasive species across continents: genetic diversity of North American and European Colorado potato beetle populations. Molecular Ecology 14, 4207-4219.

Gullan, P.J., Kosztarab, M., 1997. Adaptations in scale insects. Annual Review of Entomology 42, 23-50.

Heng, E.T., Forbes, V.L., 2006. Christmas Island: remote no more. In: Rumley, D., Forbes, V.L., Griffin, C. (Eds.), Australiás Arc of Instability. Springer, Berlin, pp. 69-82.

Herbert, P.D.N., Cywinska, A., Ball, S.L., deWaard, J.R., 2003. Biological identifications through DNA barcodes. Proceedings of the Royal Society of London, Series B 270, 313-321.

Howard, F.W., Pemberton, R.W., 2003. The lobate lac scale insect, a new pest of trees and shrubs in Florida: implications for the Caribbean region. Proceedings of the Caribbean Food Crops Society 39, 91-94.

Howard, F.W., Pemberton, R.W., Hodges, G.S., Steinberg, B., McLean, D., Liu, H., 2006. Host plant range of lobate lac scale, Paratachardina lobata, in Florida. Proceedings of the Florida State Horticultural Society $119,398-408$.

Kondo, T., Gullan, P.J., 2007. Taxonomic review of the lac insect genus Paratachardina Balachowsky (Hemiptera: Coccoidea: Kerriidae), with a revised key to genera of Kerriidae and description of two new species. Zootaxa 1617, 1-41.

Mestre, N.M., Ravelo, H.G., Hodges, G.S., 2006. Paratachardina lobata lobata (Chamberlin) (Hemiptera: Coccoidea: Kerriidae) un nuevo registro de insecto escama para Cuba. Centro Agrícola, Cuba 33, $21-24$.
Pemberton, R.W., 2003a. Invasion of Paratachardina lobata lobata (Hemiptera: Kerriidae) in South Florida: a snapshot sample of an infestation in a residential yard. Florida Entomologist 86, 373-377.

Pemberton, R.W., 2003b. Potential for biological control of the lobate lac scale, Paratachardina lobata lobata (Hemiptera: Kerriidae). Florida Entomologist 86, 353-360.

Pemberton, R.W., Nguyen, R., Winotai, A., Howard, F.W., 2006. Host acceptance trials of Kerria lacca (Kerriidae) parasitoids from northern Thailand on the pest lobate lac scale (Paratachardina lobata) (Kerriidae). Florida Entomologist 89, 336-339.

Qin, T.-K., Gullan, P.J., Beattie, G.A.C., Trueman, J.W.H., Cranston, P.S., Fletcher, M.J., Sands, D.P.A., 1994. The current distribution and geographical origin of the scale insect pest Ceroplastes sinensis (Hemiptera: Coccidae). Bulletin of Entomological Research 84, 541550.

Rambaut, A., 1996. Se-Al sequence alignment editor, ver. 1.0 alpha 1. Oxford: Department of Zoology, University of Oxford. Available at $<$ http://evolve.zoo.ox.ac.uk/ $>$.

Schauff, M.E., 2005. Ammonoencyrtus carolinensis, n. comb. (Hymenoptera: Encyrtidae), a parasite of lobate lac scale Paratachardina lobata (Chamberlin) (Hemiptera: Kerriidae). Proceedings of the Entomological Society of Washington 107, 115-118.

Scheffer, S.J., Grissell, E.E., 2003. Tracing the geographical origin of Megastigmus transvaalensis (Hymenoptera: Torymidae): an African wasp feeding on a South American plant in North America. Molecular Ecology 12, 415-421.

Schroer, S., Pemberton, R.W., 2007. Host acceptance trials of parasitoids from Indian Paratachardina lobata (Hemiptera: Kerriidae) on the invasive lobate lac scale in Florida. Florida Entomologist 90, 545-552.

Schroer, S., Pemberton, R.W., Selvaraj, P., 2007. Parasitoids of Paratachardina lobata (Hemiptera: Kerriidae): surveys for biological control of the invasive lobate lac scale. Journal of Applied Entomology 132, $17-22$.

Simon, C., Frati, F., Beckenbach, A., Crespi, B.J., Liu, H., Flook, P., 1994. Evolution, weighting and phylogenetic utility of mitochondrial gene sequences and a compilation of conserved polymerase chain reaction primers. Annals of the Entomological Society of America 87, 651-701.

Strand, M.R., Pech, L.L., 1995. Immunological basis for compatibility in parasitoid-host relationships. Annual Review of Entomology 40, $31-56$.

Swofford, D.L., 2003. Phylogenetic Analysis Using Parsimony (*and other methods) Version 4. Sinauer Associates, Sunderland, Massachusetts.

Varshney, R.K., 1976. A checklist of insect parasites associated with lac. Oriental Insects 10, 55-78.

Varshney, R.K., 1977. Taxonomic studies on lac insects of India (Homoptera: Tachardiidae). Oriental Insects 1976 (Suppl. 5), 1-97.

Williams, D.J., Granara de Willink, M.C., 1992. Mealybugs of Central and South America. C.A.B. International, Wallingford, pp. 635.

Whiting, M.F., Carpenter, J.C., Wheeler, Q.D., Wheeler, W.C., 1997. The Strepsiptera problem: phylogeny of the holometabolous insect orders inferred from $18 \mathrm{~S}$ and $28 \mathrm{~S}$ ribosomal DNAsequences and morphology. Systematic Biology 46, 1-68. 